\title{
Genetic parameters and genotype $x$ environment interaction for productivity, oil and protein content in soybean
}

\author{
Rafael Delmond Bueno ${ }^{1,4 *}$, Leandro Luiz Borges ${ }^{4}$, Klever Márcio Antunes Arruda ${ }^{2}$, Leonardo \\ Lopes Bhering ${ }^{3}$, Everaldo Gonçalves de Barros ${ }^{3}$ and Maurílio Alves Moreira ${ }^{1,4}$ \\ ${ }^{1}$ Departamento de Bioquímica e Biologia Molecular, 36.570-000, Viçosa, MG, Brazil. \\ ${ }^{2}$ Instituto Agronômico do Paraná (IAPAR), Área de Melhoramento Vegetal, 86.047-902, Londrina, PR, Brazil. \\ ${ }^{3}$ Departamento de Biologia Geral, Universidade Federal de Viçosa, 36.570-000, Viçosa, MG, Brazil. \\ ${ }^{4}$ Instituto de Biotecnologia Aplicada à Agropecuária (BIOAGRO), Universidade Federal de Viçosa, 36.570-000, \\ Viçosa, MG, Brazil.
}

Accepted 11 September, 2013

\begin{abstract}
The objective of this work was to evaluate the interaction between genotypes and environments for productivity and content of protein and oil, as well as to estimate the genetic parameters and genetic variation among 18 genotypes of soybean grown in four environments. The experiments were set up in the 2006/2007 agricultural year in a randomized block design with three repetitions. The content of protein and oil in the beans was determined by near infrared spectroscopy (NIR). In the four environments the significance was noted for genetic variability and genotype $x$ environment interactions for all traits. Estimates of the heritability of the analyzed variables were high, indicating potential for selecting superior genotypes in breeding programs. In partial correlation analysis only the oil and protein contents were significantly correlated. Correspondence was observed between the UPGMA and Tocher estimation methods, dividing the genotypes into three heterotic groups, with the protein content being the character that most contributed to genetic diversity.
\end{abstract}

Key words: Glycine max, genetic improvement, quantitative traits, biometrics.

\section{INTRODUCTION}

With production estimated at 82 million tons of grain for the 2012/2013 harvest, Brazil is the world's second biggest soybean producer and is likely to become the greatest exporter of this legume in this agricultural year (USDA, 2013). The success of soybean cultivation is attributed to the combination of its high protein content (about $40 \%$ ) and oil content (about 20\%), together with satisfactory productivity levels for the grain in a range of soils and climatic conditions.

Developing productive cultivars with significantly incremented protein and/or oil content is one of the main objectives of soybean breeding programs (Mahmoud et al., 2006). Protein and oil content in soybean grains involves quantitative genetic control and is influenced by environment (Bonato et al., 2000). The existence of a negative correlation between protein and oil content in soybean grains has prevented the simultaneous increase of these characters in commercial lines (Rodrigues et al., 2010). The existence of interaction between genotypes and environments $(G \times E)$ constitutes one of the main problems for breeding programs, be it at the selection stage or in the recommendation of cultivars. The importance of this interaction means that the breeder has to evaluate its magnitude and significance, quantify 
Table 1. Geographical information and climatic conditions of the environments.

\begin{tabular}{lcccc}
\hline Environment & Altitude $(\mathbf{m})$ & Latitude & Annual average rainfall $(\mathbf{m m})$ & Annual average temperature $\left({ }^{\circ} \mathbf{C}\right)$ \\
\hline Perdizes-MG & 973 & $19^{\circ} 35^{\prime} 33^{\prime \prime}$ & 1575 & 20.4 \\
São Gotardo-MG & 1055 & $19^{\circ} 29^{\prime} 59^{\prime \prime}$ & 1427 & 20.7 \\
Presidente Olegário-MG & 947 & $18^{\circ} 24^{\prime} 50^{\prime \prime}$ & 1475 & 20.4 \\
Mineiros-GO & 750 & $17^{\circ} 34^{\prime} 14^{\prime \prime}$ & 2005 & 23.0 \\
\hline
\end{tabular}

its effects on breeding techniques as well as to adopt procedures to minimize or take advantage of the interaction (Cruz and Carneiro, 2003).

Estimates of heritability and genetic correlations are essential to the success of any strategy used in plant breeding (Laviola et al., 2010). Estimates of heritability in the broad sense are important in plants because they are connected to selection, and the larger the estimated value of this parameter is, the greater will be the chance of success with selection (Gravois and Bernhardt, 2000).

The objective of this work was to evaluate the interaction of genotypes and environments with regard to productivity and protein and oil content, as well as estimating the genetic parameters and genetic variability among 18 soybean genotypes cultivated in four distinct environments.

\section{METHODS}

In the 2006/2007 agricultural year 18 soybean genotypes were evaluated, which had been supplied by COOPADAP (Agricultural Cooperative of Alto Paranaíba), in the following places: Perdizes (Minas Gerais-MG), São Gotardo (MG), Presidente Olegário (MG) and Mineiros (Goiás-GO) (Table 1). The genotypes used were CS01736 (1), CS02884 (2), CS02564 (3), CS02449 (4), CS02731 (5), CS01873 (6), CS02988 (7), CS021026 (8), Luziânia (9), Monarca (10), Garantia (11), Elite (12), CS02521 (13), CS02302 (14), CS821 (15), CS801 (16), MSOY8001 (17) and Vencedora (18).

The experiment was conducted with 18 genotypes and the design was randomized blocs with three repetitions. The plots were constituted of four rows, each $5 \mathrm{~m}$ long and with a space of $0.5 \mathrm{~m}$ between them. The useful area of the plot included only the plants present in the two central rows.

To quantify the protein and oil content, $10 \mathrm{~g}$ of seeds of each genotype were collected. The seeds were triturated in a mill to achieve suitable granules for reading in a near infrared spectrometer (NIR, Agrosystem equipment, model Instalab 600 Product Analyzer).

Individual and joint analyses of variance were carried out, based on a randomized simple factorial model to test the effect of genotypes and of the genotype $x$ environment interaction by means of $\mathrm{F}$ test, using the statistical model:

$Y_{i j k}=\mu+G_{i}+A_{j}+G A_{i j}+\varepsilon_{i j k}$

In which, $\mathrm{Y}_{\mathrm{ijk}}=$ value of the character for the $\mathrm{i}^{\text {th }}$ genotype $(\mathrm{i}=1,2$, $\ldots, g)$ in the $j^{\text {th }}$ environment $(j=1,2, \ldots, j)$ in the $k^{\text {th }}$ bloc $(K=1,2, \ldots$, $K) ; \mu=$ general mean; $G_{i}=$ effect of the $i^{\text {th }}$ genotype; $A_{j}=$ effect of the $j^{\text {th }}$ environment; $\mathrm{GA}_{\mathrm{ij}}=$ effect of the interaction of the $\mathrm{i}^{\text {th }}$ genotype with the $\mathrm{j}^{\text {th }}$ environment, and $\varepsilon_{\mathrm{ijk}}=$ random error.
The experimental variation coefficients were also estimated $\left(\mathrm{CV}_{\mathrm{e}} \%\right)$, as well as the genetic and environmental parameters for each of the characters analyzed in each environment. The phenotypic, genetic and residual correlations were estimated for all the pairs of characters in each environment, and path analysis was used to obtain the partial correlation coefficients between the characters.

To analyze genetic diversity, estimates of dissimilarity were obtained using the generalized distance of Mahalanobis and grouped by Tocher method, cited by Rao (1952). The 18 genotypes were grouped based on the genetic similarity matrix using the hierarchical method known as the Unweighted Pair-Group Method with Arithmetic Mean (UPGMA), and the quality of the dendogram nodes was measured by bootstrap with 5000 simulations. The dendogram cutoff point for the formation of groups was obtained by the Mojena (1977) method.

The cophenetic correlation coefficient was also estimated to verify the original values of dissimilarity compared with those represented in the dendogram. The significance of this coefficient was measured by Student t-test at $1 \%$ probability with $n-2=151$ degrees of liberty, in which $n$ is equal to 153 distances resulting from the pairwise combination of 18 genotypes. The relative importance of the characters in relation to the genetic diversity among the genotypes was studied according to Singh (1981). All the statistical analyses were carried out using the GENES computational application (Cruz, 2013).

\section{RESULTS AND DISCUSSION}

The variance components and the estimates for genetic parameters for each character are shown in Table 2. Genetic variability $(p \leq 0.05)$ for the three characters was seen in the four environments. Genotypic variance is considered one of the most important parameters for quantifying the breeding potential of a population, and the existence of genotypic variance among the tested averages indicates the viability of the use of selective techniques in genotypes (Cruz et al., 2004). High genetic variance values were found for productivity (Table 2 ), reflecting directly on the magnitude of the heritability values. In the broad sense heritability estimates values obtained for productivity $(83.5 \%)$, protein content $(80.6 \%)$ and oil content $(79.4 \%)$ were high, indicating that there is potential for selection of superior genotypes for the improvement of these traits. These values were higher than those found by Rodrigues et al. (2010) for oil content $(71.61 \%)$ and protein content $(62.36 \%)$; as well as for productivity $(77 \%)$ found by Aditya et al. (2011). In general, grain production is a character that has medium to low heritability, and it can be attributed to the quantitative behavior of this character, due to the large 
Table 2. Mean genetic and environmental parameters of the characters productivity, oil content and protein content for each environment.

\begin{tabular}{|c|c|c|c|c|c|c|c|c|c|c|c|c|}
\hline \multirow[b]{2}{*}{ Parameter $^{1}$} & \multicolumn{3}{|c|}{ Mineiros } & \multicolumn{3}{|c|}{ Perdizes } & \multicolumn{3}{|c|}{ Presidente Olegário } & \multicolumn{3}{|c|}{ São Gotardo } \\
\hline & $\begin{array}{c}\text { Productivity } \\
\text { (Kg/ha) }\end{array}$ & $\begin{array}{l}\text { Oil } \\
(\%)\end{array}$ & $\begin{array}{c}\text { Protein } \\
(\%)\end{array}$ & $\begin{array}{c}\text { Productivity } \\
\text { (Kg/ha) }\end{array}$ & $\begin{array}{l}\text { Oil } \\
(\%) \\
\end{array}$ & $\begin{array}{c}\text { Protein } \\
(\%)\end{array}$ & $\begin{array}{c}\text { Productivity } \\
\text { (Kg/ha) }\end{array}$ & $\begin{array}{l}\text { Oil } \\
(\%)\end{array}$ & $\begin{array}{c}\text { Protein } \\
(\%)\end{array}$ & $\begin{array}{c}\text { Productivity } \\
\text { (Kg/ha) }\end{array}$ & $\begin{array}{l}\text { Oil } \\
(\%)\end{array}$ & $\begin{array}{c}\text { Protein } \\
(\%)\end{array}$ \\
\hline$\mu$ & $2,910.04$ & 21.85 & 43.76 & $2,202.05$ & 21.40 & 43.88 & $3,249.01$ & 22.68 & 41.26 & $4,045.55$ & 22.49 & 40.88 \\
\hline$V_{g}$ & $387,643.21^{* *}$ & $0.07^{\star \star}$ & $3.28^{*}$ & $48,003.57^{*}$ & $0.37^{* *}$ & $1.17^{* \star}$ & $335,299.30^{* *}$ & $0.53^{* *}$ & $1.67^{* *}$ & $234,077.12^{* *}$ & $0.71^{* *}$ & $1.67^{\star \star}$ \\
\hline$h^{2}(\%)$ & 0.95 & 0.81 & 0.88 & 0.61 & 0.85 & 0.90 & 0.84 & 0.89 & 0.88 & 0.7527 & 0.88 & 0.95 \\
\hline $\mathrm{CV}_{\mathrm{e}}(\%)$ & 8.78 & 4.33 & 2.60 & 13.88 & 2.05 & 1.39 & 13.54 & 1.92 & 1.97 & 11.87 & 2.34 & 1.23 \\
\hline \multicolumn{7}{|c|}{ Mean values } & \multicolumn{6}{|c|}{ Genetic and environmental parameters } \\
\hline Parameter $^{1}$ & \multicolumn{2}{|c|}{ Productivity } & \multicolumn{2}{|c|}{ Protein } & Oil & & Parameter $^{1}$ & \multicolumn{2}{|c|}{ Productivity } & Protein & \multicolumn{2}{|r|}{ Oil } \\
\hline$\mu$ & \multicolumn{2}{|c|}{$3,101.67$} & \multicolumn{2}{|c|}{42.44} & 22.10 & & $\rho$ & \multicolumn{2}{|c|}{41.92} & 42.40 & \multicolumn{2}{|r|}{33.70} \\
\hline Maximum & \multicolumn{2}{|c|}{$3,849.81$} & \multicolumn{2}{|c|}{44.49} & 22.81 & & $h^{2}(\%)$ & \multicolumn{2}{|c|}{83.50} & 80.64 & \multicolumn{2}{|r|}{79.40} \\
\hline Minimum & \multicolumn{2}{|c|}{$1,881.30$} & \multicolumn{2}{|c|}{40.20} & 20.72 & & $V_{G \times A}$ & \multicolumn{2}{|c|}{82.567 .60} & 0.84 & \multicolumn{2}{|r|}{0.15} \\
\hline \multirow[t]{2}{*}{$\mathrm{CV}_{\mathrm{e}}$} & \multirow{2}{*}{\multicolumn{2}{|c|}{12.46}} & \multirow{2}{*}{\multicolumn{2}{|c|}{1.91}} & 2.78 & & $V_{e}$ & \multicolumn{2}{|c|}{$149,433.36$} & 1.10 & \multicolumn{2}{|r|}{0.27} \\
\hline & & & & & & & $\mathrm{CV}_{\mathrm{g}} / \mathrm{CV}_{\mathrm{e}}$ & \multicolumn{2}{|c|}{1.06} & 1.30 & \multicolumn{2}{|r|}{0.85} \\
\hline
\end{tabular}

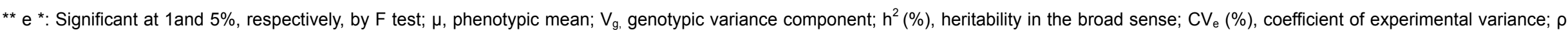

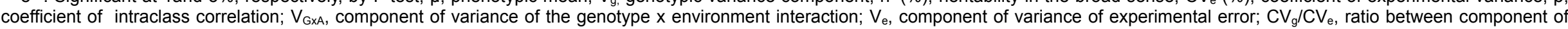
genotypic variance and experimental error.

number of genes involved, allowing greater environmental influences and the existence of genes that present action due to dominance deviations. On the hand, the characteristics protein and oil contents have medium to high heritability. It was observed that the genotype $x$ environment interaction was significant $(p \leq 0.01)$ for the three characters in the four environments. Variance analysis (Vgxe) showed that productivity was the character with most sensitivity to environmental variation. This result was similar to that found by Zhe et al. (2010), who showed that productivity is more sensitive to environmental variation than protein and oil contents.

Sediyama et al. (1993) showed that oil content is higher when the soybean is cultivated in warmer environments, and that the oil content is lower when the seeds ripen in cold temperatures. According to Dardanelli et al. (2006), protein and oil will vary in an inverse relationship due to the changes in temperature of plant development. However, the temperature seems not to be directly related to the protein content but indirectly influence it via the oil content, since these two characteristics are inversely correlated.

The oil content has a significant influence of component interaction GxE. According to Rocha et al. (2002), the effects of factors such as sowing dates, locations, years and their interactions have been evaluated for oil content. Based on these studies were verified a pronounced effect of the interaction genotype $x$ year, outweighing the effects of sowing date and planting location.

In Australia, Rose (1988) evaluated seven soybean genotypes in multiple planting seasons, finding differences in grain yield due to planting date, genotype and genotype $x$ planting season. The oil seed percentage for late planting date decreased $1.7 \%$. Pfeiffer et al. (1995) studied the genotype $x$ environment interaction for the traits grain yield, oil content and protein in 32 lines planted in four different locations in two U.S. states. Significant effect was detected for interaction both within and between states for oil content and protein.

The estimates of mean coefficients of experimental variation $\left(\mathrm{CV}_{\mathrm{e}}\right)$ were low for the evaluated characters (Table 2). Rodrigues et al. (2010) found $\mathrm{CV}_{\mathrm{e}}$ of 4.1 and $3.8 \%$ for protein and oil content, respectively, which were higher than values found in this work. The value of $\mathrm{CV}_{\mathrm{e}}$ for productivity was $12.46 \%$, lower than the value of $16 \%$ established as ideal for soybean productivity, suggested by Carvalho et al. (2003). In Table 2 the values for the $\mathrm{CV}_{g} / C V_{e}$ ratio are shown, assuming values higher than the unity for the characters protein content and productivity. These 
Table 3. Estimate of simple and partial correlation coefficients.

\begin{tabular}{|c|c|c|c|c|c|c|c|c|c|c|c|c|}
\hline \multirow{2}{*}{ Correlations } & \multicolumn{3}{|c|}{ Mineiros } & \multicolumn{3}{|c|}{ Perdizes } & \multicolumn{3}{|c|}{ Presidente Olegário } & \multicolumn{3}{|c|}{ São Gotardo } \\
\hline & Phenotypic & Genotypic & Environmental & Phenotypic & Genotypic & Environmental & Phenotypic & Genotypic & Environmental & Fenotípica & Genotípica & Ambiental \\
\hline Prod. x Prot. & $-0.70^{\star \star \star}$ & $-0.75^{++}$ & $-0.11^{\mathrm{ns}}$ & $-0.50^{*}$ & $-0.56^{+}$ & $-0.45^{++}$ & $-0.18^{\text {ns }}$ & $-0.24^{n s}$ & $0.20^{\mathrm{ns}}$ & $-0.26^{n s}$ & $-0.28^{n s}$ & $-0.25^{n s}$ \\
\hline Prod. x Óleo & $0.59^{\star \star}$ & $0.96^{++}$ & $0.23^{\text {ns }}$ & $0.37^{n s}$ & $0.33^{n s}$ & $0.53^{++}$ & $-0.08^{n s}$ & $-0.09^{n s}$ & $-0.07^{n s}$ & $0.53^{\star}$ & $0.60^{+}$ & $0.25^{n s}$ \\
\hline \multirow[t]{2}{*}{ Prot. x Óleo } & $-0.70^{\star \star}$ & $-0.94^{++}$ & $-0.46^{++}$ & $-0.76^{\star \star}$ & $-0.79+$ & $-0.60^{++}$ & $-0.62^{\star \star}$ & $-0.63^{++}$ & $-0.56^{++}$ & $-0.84^{\star \star}$ & $-0.86^{++}$ & $-0.58^{++}$ \\
\hline & ean values & & & & & & & & & & & \\
\hline Correlations & Simple r & Partial $r$ & & & & & & & & & & \\
\hline Prod. x Prot. & $-0.51^{\star}$ & -0.34 ns & & & & & & & & & & \\
\hline Prod. x Óleo & $0.41^{\mathrm{ns}}$ & $0.42^{\mathrm{ns}}$ & & & & & & & & & & \\
\hline Prot. x Óleo & $-0.75^{* *}$ & $-0.69^{\star \star}$ & & & & & & & & & & \\
\hline
\end{tabular}

${ }^{n s}$ non-significant, ${ }^{* *}$ and ${ }^{*}$ : Significant at 1 and $5 \%$, respectively, by $t$ test; ${ }^{\text {ns }}$ non-significant, ${ }^{++}$and ${ }^{+}$: Significant at 1 and $5 \%$, respectively, by the bootstrap method with 5,000 simulations;

Prod. = Productivity; Prot. $=$ Protein

values are considered ideal for selection (Vencovsky and Barriga, 1992; Cruz et al., 2004). Considering the oil content character, this parameter was below the unit, indicating low potential for selection of these genotypes for improving oil content. By analysis of the variance component $V_{g}$ for oil content, it can be seen that this value was very low in the four environments, which explains why the $\mathrm{CV}_{\mathrm{g}} / \mathrm{CV}_{\mathrm{e}}$ ratio was below the unit.

The results of phenotypic, genotypic and environmental correlations are presented in Table 3. The genotypic correlations were higher than the phenotypic and environmental ones, with the exception of the environment Perdizes (MG), in which the environmental correlation was higher than phenotypic and genotypic correlations for the variables productivity x oil. Genotypic correlations with the same sign and greater values than the phenotypic ones are common in soybean (Moro et al., 1992; Taware et al., 1997; Lopes et al., 2002; Rodrigues et al., 2010). Chand (1999) performed experiments on different varieties of soybean and for all characters studied were higher than the phenotypic and environmental correlation coefficients.

Studies on genotypic, phenotypic and environmental correlations in soybean have involved characters collected from flowering to maturity, emphasizing productivity and its components and, in recent decades, involving quantitative and qualitative analyzes of oil and protein. (Sharma, 1979; Cecon et al., 1993; Akhter and Sneller, 1996a, b; Taware et al., 1997; Wilcox, 1998; Xinhai et al., 1999; Morrison et al., 2000; Wilcox and Shibles, 2001; Alt et al., 2002). Estimates of partial correlation coefficients were made for the pairs of variables analyzed, where only the content of oil and protein correlated significantly $(P \leq 0.05)$ (Table 3$)$. For the pairs in protein $\mathrm{x}$ productivity and oil $\mathrm{x}$ productivity, the high coefficient of simple correlation can be explained by the influence of a third variable or group of variables that favored the significance of the correlation (Cruz and Carneiro, 2003).

The results presented in Table 3 indicate that the increase in the variables productivity and oil content will mean a reduction in protein content.
Similar results were found by Bonato et al. (2000) and Rodrigues et al. (2010). According to Cruz et al. (2004), only genetic correlations involve a heritable association and can be used for orienting breeding programs.

In choosing the progenitors to be used in hybrid combinations that will produce superior segregant populations, the genotypes were grouped by the Tocher method (Table 4). The grouping of genotypes is done by identifying the most similar pair within the dissimilarity matrix; that is, the pair with the lowest estimated distance. By this means the genotypes were grouped into three similar or heterotic groups, with the genotype Elite separate from the others because this grouping method is influenced by the distance from already grouped genotypes (Vasconcelos et al., 2007).

For the study of genetic similarity, the UPGMA method was used and the resulting dendogram is presented in Figure 1. This method is the most widely used one in studies of genetic diversity, in that it considers the mean measurements of dissimilarity and thus avoids characterizing dissimilarity by extreme values between genotypes (Cruz et al., 2004). Using the method 
Table 4. Tocher grouping of the 18 soybean genotypes based on Mahalanobis distance.

\begin{tabular}{cl}
\hline Group & Genotype \\
\hline I & CS02 731, CS821, CS01 736, CS02 988, CS02 449, CS02 884, CS02 564, Luziania, \\
II & CS 01 873, CS801, Garantia, Monarca, CS02 1026, CS02 302 and CS02 521 \\
III & ESOY 8001 and Vencedora \\
\hline
\end{tabular}

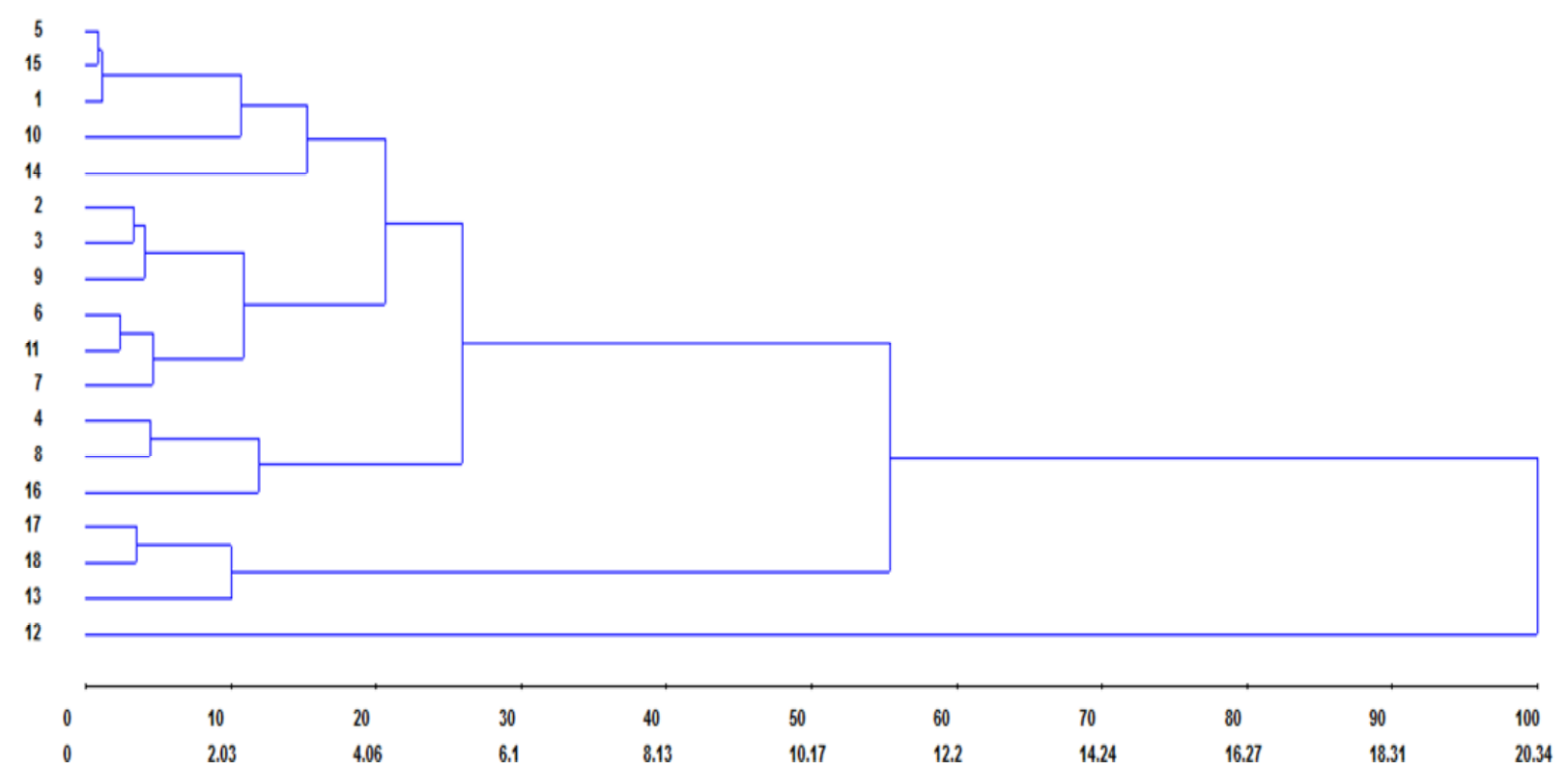

Figure 1. Dendrogram created from the pattern of dissimilarity quantified by the UPGMA method for the 18 soybean genotypes based on the Mahalanobis distance. The cophenetic correlation coefficient $(r)$ was 0.77 , with $p \leq 0.01$ by t-test.

of Mojema (1977) the cutoff point in the dendogram was established for the formation of groups at a level of $\theta=9.83$, with $\theta$ being the level at which branches of the dendogram fuse. It is thus possible to form three cut-offs at different stages in the dendogram, as can be seen in Figure 1. The first group contains only the genotype Elite; the second has the genotypes CS02 521, MSOY 8001 and Vencedora and the third the 14 remaining genotypes. There was some correspondence between the UPGMA method and the Tocher method in that both isolated the genotype Elite from the others. The second group formed by the UPGMA method was quite similar to that formed by Tocher, showing only one difference in that it included genotype CS02 521.

In this study the cophenetic correlation coefficient $(r)$ was 0.77 with $p \leq 0.01$, grouping with the distance matrix of the genotypes. It should be borne in mind that even if $r$ is significant $(p \leq 0.01)$, the values near the unit should be preferred, because these indicate greater consistency in the grouping pattern (Cruz et al., 2004; Cargnelutti Filho et al., 2010).

The character that most contributed to the genetic diversity of the genotypes, according to the methodology of Singh (1981), was protein content, followed by productivity and oil content, as shown in Figure 2. Studies contribution of characters for genetic diversity are important to select characters that best discriminate the accessions and discard others that contribute little to discriminate genotypes of a given species. The use of parents with insufficient genetic diversity in the formation of populations for hybridization reduces the genetic variability for quantitative traits (Fehr, 1987)

\section{Conclusions}

The existence of the genotype $x$ environment interaction for the three characters will have an influence on the selection gain and will make it difficult to recommend cultivars with broad adaptability. The $\mathrm{CV}_{\mathrm{g}} / \mathrm{CV}_{\mathrm{e}}$ ratio estimated for the characters productivity and protein and oil content showed values close to or above the unit, considered ideal for selection practices. Estimates of the simple correlation coefficient showed the existence of a 


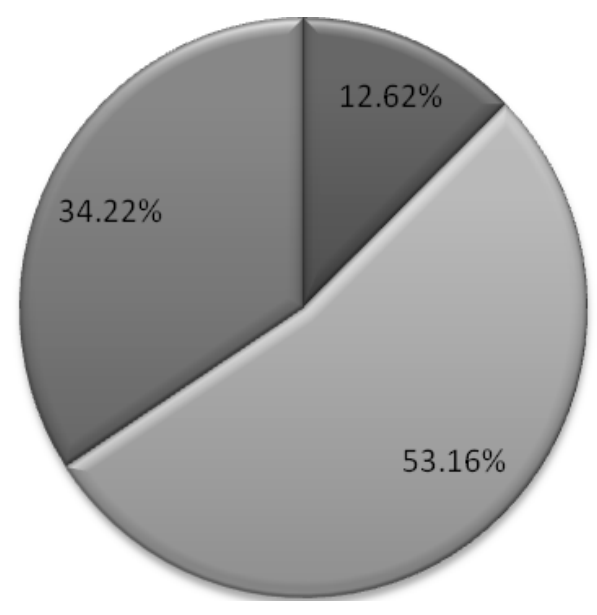

Oil content

$\square$ Protein content

$\square$ Productivity

Figure 2. Relative contribution of the characters productivity and oil and protein content for the genotypic diversity of the accessions, using the methodology of Singh (1981).

significant and negative correlation between productivity and protein content and between oil content and protein content. In the estimates of partial correlation coefficients, only the pair protein content $x$ oil content showed a significant correlation. The genotypes were grouped into three similarity groups based on the divergences between the evaluated characters, and the character that most contributed to genetic diversity was protein content, followed by productivity and oil content.

\section{ACKNOWLEDGEMENTS}

The authors express their thanks to Fapemig, Capes and CNPq financial support and to COOPADAP for supplying the genetic material.

\section{REFERENCES}

Aditya JP, Bhartiya P, Bhartiya A (2011). Genetic variability, heritability and character association for yield and component characters in soybean (G. $\max ($ L.) Merrill). J. Cent. Eur. Agric. 12(1):27-34

Akhter M, Sneller CH (1996a). Yield and yield components of early maturing soybean genotypes in the mid-south. Crop Sci. 36(4):877882.

Akhter M, Sneller CH (1996b). Genotype x planting date interaction and selection of early maturing soybean genotypes. Crop Sci. 36(4):883889.

Alt BJ, Fehr WR, Welke GA (2002). Selection for large seed and high protein in two- and three-parent soybean populations. Crop Sci. 42(6):1876-1881

Bonato ER, Bertagnolli PF, Lange CE, Rubin SAL (2000). Teor de óleo e de proteína em genótipos de soja desenvolvidos após 1990. Pesq. Agro. Bras. 35(12):2391-2398.

Cargnelutti Filho A, Ribeiro ND, Burin C (2010). Consistência do padrão

de agrupamento de cultivares de feijão conforme medidas de dissimilaridade e métodos de agrupamento. Pesq. Agro. Bras. 45(3): 236-243.

Carvalho CGP, Arias CAA, Toledo JFF, Almeida LA, Kiihl RAS, Oliveira MF, Hiromoto DM, Takeda C (2003). Proposta de classificação dos coeficientes de variação em relação à produtividade e altura da planta de soja. Pesq. Agro. Bras. 38(2):187-193.

Cecon PR, Morais AR, Sediyama CS (1993). Obtenção da herdabilidade e das correlações genotípicas, fenotípicas e de ambiente nas gerações F2 e F3 de cruzamentos fatoriais em soja. Pesq. Agro. Bras. 28(12):1399-1406

Chand $P$ (1999). Association analysis of yield and its components in soybean (Glycine max L.) Merrill. Madras Agric. 86(7-9):378-381.

Cruz CD (2013). GENES - a software package for analysis in experimental statistics and quantitative genetics. Acta Sci. Agro. 35(3):271-276.

Cruz CD, Carneiro PCS (2003). Modelos biométricos aplicados ao melhoramento genético. Editora UFV, Viçosa. P. 585.

Cruz CD, Carneiro APS, Regazzi AJ (2012). Modelos biométricos aplicados ao melhoramento genético. $4^{\text {th }}$ Ed., Editora UFV, Viçosa. P. 514

Dardanelli JL, Balzarini M, Martinez MJ, Cuniberti M, Resnik S, Ramunda SE, Herrero R, Baigorri H (2006). Soybean maturity groups, environments, and their interaction define megaenvironments for seed composition in Argentina. Crop Sci. 46(5):1939-1947.

Fehr WR (1987). Principles of cultivar development. Macmillan, New York. P. 536.

Gravois KA, Bernhardt JL (2000). Heritability x environment interactions for discoloured rice kernels. Crop Sci. 40(2):314-318.

Lopes ACA, Vello NA, Pandini F, Rocha MM, Tsutsumi CY (2002). Variabilidade e correlações entre caracteres em cruzamentos de soja. Sci. Agric. 59(2):341-348.

Mahmoud AA, Natarajan SS, Bennett JO, Mawhinney TP, Wiebold WJ, Krishnan HB (2006). Effect of six decades of selective breeding on soybean protein composition and quality: A biochemical and molecular analysis. J. Agric. Food Chem. 54(11):3916-3922.

Mojena R (1977). Hierarchical grouping methods and stopping rules: an evaluation. Comput. J. 20(4):359-363.

Moro GL, Reis MS, Sediyama CS, Oliveira AB (1992). Correlação entre alguns caracteres agronômicos em soja (Glycine max (L.) Merrill). Rev. Ceres. 39:225-232.

Pfeiffer TW, Grabau LJ, Orf JH (1995). Early maturity soybean production system - genotype-X environment interaction between regions of adaptation. Crop Sci. 35(1):108-112.

Rao RC (1952). Advanced statistical methods in biometric research John Wiley and Sons, New York. P. 390.

Rocha MM, Vello NA, Lopes ACA, Maia MCC (2009). Estabilidade e adaptabilidade produtiva em linhagens de soja de ciclo médio. Rev. Ceres. 56(6):764-771. 
Rocha MM, Vello NA, Maia MCC, Lopes ACA (2002). Magnitude da interação genótipos $x$ ambientes para o caráter teor de óleo em linhagens de soja. Ver. Bras. Ole. Fib. 6:617-625.

Rodrigues JID, De Miranda FD, Ferreira A, Borges LL, Ferreira MFD, Good-God PIV, Piovesan ND, De Barros EG, CRUZ CD, Moreira MA (2010). Mapping QTL for protein and oil content in soybean. Pesq. Agro. Bras. 45(5):472-480.

Rose IA (1988). Effects of moisture stress on the oil and proteincomponents of soybean seeds. Aust. J. Agric. Res. 39(2):163-170.

Sediyama T, Pereira MG, Sediyama CS, Gomes JLL (1993). Cultura da Soja, Parte I. Editora UFV, Viçosa, P. 97.

Sharma SK (1979). Path coefficient analysis in the F2 populations of soybean grown at two locations. Indian J. Agric. Sci. 49:820-821.

Singh $D$ (1981). The relative importance of characters affecting genetic divergence. Indian J. Genet. Plant Br. 41(2):237-245.

Taware SP, Halvankar GB, Rautvm, Patil VP (1997). Variability, correlation and path analysis in soybean hybrids. Soybean Genet. Newsl. 24:96-98.
USDA, United States Department of Agriculture. Retrieved from http://www.fas.usda.gov/oilseeds/current/default.asp. Acess on: 23 Jun. 2013.

Vasconcelos ES, Cruz CD, Bhering LL, Resende Jr. MFR (2007). Método alternativo para análise de agrupamento. Pesq. Agro. Bras. 42(10):1421-1428.

Vencovsky R, Barriga P (1992). Genética Biométrica no Fitomelhoramento. Rev. Bras. Gen., Ribeirão Preto, P. 496.

Wilcox JR (1998). Increasing seed protein in soybean with eight cycles of recurrent selection. Crop Sci. 38:1536-1540.

Zhe Y, Lauer JG, Borges R, Leon N (2010). Effects of genotype $\times$ environment interaction on agronomic traits in soybean. Crop Sci. 50: 696-702. 